
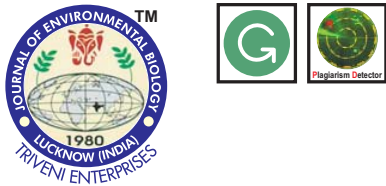

DOI : http://doi.org/10.22438/jeb/38/6(SI)/04

\title{
Annual phytoplankton dynamics in La Antigua River, Mexico
}

Authors Info

M.L. Gaytán-Herrera',

\section{E. Cuna-Pérez ${ }^{2}$ and}

P. Ramírez-García ${ }^{1 *}$

${ }^{1}$ Research and Postgraduate Division, UNAM, FES-Iztacala, Av. de los Barrios No. 1, 54090

Tlalnepantla, Estado de México,

México

${ }^{2}$ PILT Project, Paleolimnology Laboratory, UNAM, FES-Iztacala,

Av. de los Barrios No. 1, 54090

Tlalnepantla, Estado de México, México

${ }^{*}$ Corresponding Author Email : micro@unam.mx

Key words

Diatoms

La Antigua River

Phytoplankton

Tropical rivers

Publication Info

Paper received : 20.07.2016

Revised received: 21.04 .2017

Re-revised received: 19.05 .2017

Accepted :06.06.2017

\section{Abstract}

Aim: To contribute to the knowledge of rivers in Mexico, we studied the phytoplankton abundance and diversity over a year in LaAntigua River, east Mexico.

Methodology: Monthly sampling was performed for one year (March 2013 to February 2014), at 5 stations. Physicochemical parameters and chlorophyll-a were analyzed. A diagram of Holston-Tukey was performed to identify the dominant, constant, temporary and rare species Detrended Correspondence Analysis was applied to find possible links between species and environmental variables. Shannon-Wiener index was calculated.

Results: Mean water temperature was $26^{\circ} \mathrm{C}$ and depth was $1.7 \mathrm{~m}$, dissolved oxygen was $8.9 \mathrm{mg} \mathrm{l}^{-1}, \mathrm{pH}$ was 7.8 , turbidity value was 10.6 NTU, conductivity was $488 \mu \mathrm{S} \mathrm{cm}-{ }^{1}$, SRP and nitrate were $2.6 \mathrm{ug} \mathrm{I}^{-1} \mathrm{PO}_{4}^{-3}-\mathrm{P}$ and $0.6 \mathrm{mg} \mathrm{I}^{-1} \mathrm{NO}_{3}-\mathrm{N}$, chlorophyll-a was 5 $\mu \mathrm{g} \mathrm{I}^{-1}$. About 200 taxa of microalgae were recorded. Diatoms were dominated. Chlorophyceae were rich in species. Cyanoprokaryota ranked third in species richness, Euglenophyceae, Dinophyceae, Cryptophyceae and Crysophyceae had a lower richness.

Interpretation: Stations 2 and 3 had the highest contamination by wastewater discharges of the population of La Antigua. Stations 4 and 5 were separated due to increases in salinity. These stations are the closest to the sea. Station 1 is likely to be cleaner and less salty.
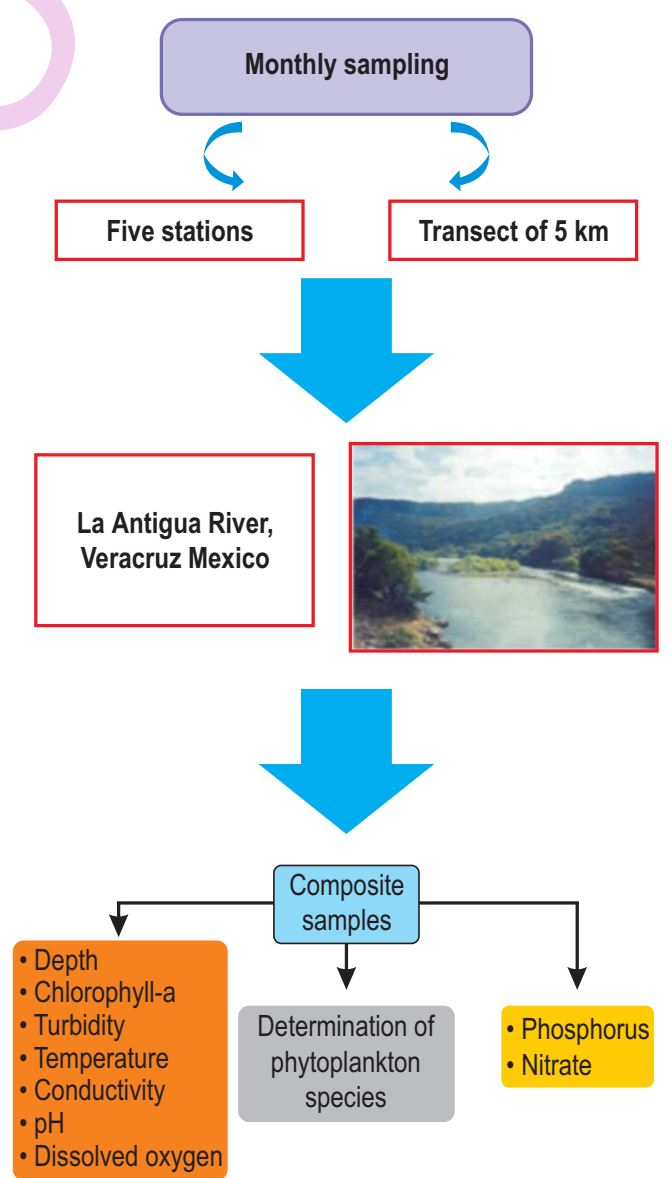

To identify as dominant, constant, temporary and rare species 


\section{Introduction}

In Mexico, the study of riverine phycoflora has focused mainly on benthic algae, since these are more common in the presence of high currents. Studies on rivers date back to 1980s (Montejano et al., 2000; Valadez et al., 1996). The phycoflora in the central part of Mexico is constituted by a community indicative of clean waters. The most representative genera are Cladophora, Spirogyra, Zygnema,Rhizoclonium, Oedogonium, Chara, Nitella, Vaucheria, Compsopogon, Hildenbrandia, Audouinella, Batrachospermum (Carmona and Necchi 2001; Cartajena and Carmona, 2009), which serve as substrate to benthic diatoms and cyanoprokaryota (e.g. Chamaesiphon, Phormidium, Blennothrix, Schizothrix, Homoeothrix, Komvophoron, Microcoleus, Leibleinia, Heteroleibleinia and Xenotholos) (Montejano et al., 2000; Montejano et al., 2000). Central Mexican rivers (at high altitude), where the climate is colder, are characterized by a temperate climate phycoflora, such as the rivers of North America and Europe (Ramírez et al., 2001, 2007).

Studies of phytoplankton in these environments are scarce. However, in large rivers, where flow velocity decreases, a true potamoplanktonic community constituted by phytoplankton and zooplankton is present, as reported in Moreno-Ruiz et al. (2008), where 298 species at Tehuantepec river (Mexico), were found, with a dominance of diatoms (42\%), followed by Chlorophyceae and cyanoprokaryota $(29 \%$ and $18 \%$, respectively).

To contribute to knowledge of these water systems, we conducted an annual sampling effort in La Antigua, a shallow, wide river located in eastern Mexico. The diversity of aquatic organisms (flora and fauna) as well as physicochemical characteristics of water in this the basin have been little studied (CONABIO, 2000). This contribution describes temporal and spatial variations of main phytoplankton species that characterize this ecosystem and its relationship with the main environmental physicochemical variables.

Study area : La Antigua River arises on the eastern slope of the Sierra Madre Oriental (Fig. 1). It has a catchment area of 2,827 $\mathrm{km}^{2}$ (0 to 3.000 ma.s.I.), with an average surface runoff of 2139 million $\mathrm{m}^{3}$ year ${ }^{-1}$ and flows runs along for $139 \mathrm{~km}$ into the Gulf of Mexico. The river carries agrochemical pollution, domestic and industrial wastes and with deforestation at the top and bottom of the basin; in the middle of the basin there are cloud forests (CONAGUA, 2011).

The climate of the area is mainly warm $\left(18-26^{\circ} \mathrm{C}\right)$, subhumid with heavy and moderate rains from July to September and November to March, respectively ( 500 to $2500 \mathrm{~mm}$ ) and a dry and hot season for the remaining months (Williams-Linera, 2007). La Antigua river basin is a High Biodiversity Area and Hydrological Priority (CONABIO, 2000).

\section{Materials and Methods}

Monthly sampling was performed for one year (March 2013 to February 2014$)$, at 5 stations $\left(19^{\circ} 19^{\prime} 15.9^{\prime \prime}\right.$ to $19^{\circ} 19^{\prime}$ $55.7^{\prime \prime} \mathrm{N}$ and $96^{\circ} 19^{\prime} 26.5$ to $96^{\circ} 19^{\prime} 46.6^{\prime \prime} \mathrm{W}$ ). In this study, we analyzed: depth (sounding line), water temperature, conductivity (K25), dissolved oxygen (YSI 55), pH (Conductronic potentiometer), soluble reactive phosphorus (SRP), nitrates (YSI 9500 photometer), turbidity and chlorophyll-a (Turner 10-AU fluorometer). For phytoplankton analysis, $500 \mathrm{ml}$ of sample was fixed with lugol and abundance count was done using an inverted light microscope (Carl Zeiss-D) with $10 \mathrm{ml}$ sedimentation chambers following the Utermhöl method (APHA, 1995). The phytoplankton identification was done, as far as possible, to species level using standard literature (e.g. Krammer and LangeBertalot, 1986,1991a,b; Comas, 1996; Komárek and Anagnostidis, 1999; Komárek, 2003; Komárek and Anagnostidis, 2005).

For diatoms identification, frustules were cleaned using acid digestion (Battarbee, 1986). Once free of organic material, the frustules were mounted in resin NAPHRAX for observation under a light microscope with phase contrast (Zeiss). Frustules were also mounted on aluminum cylinders for observation with scanning electron microscopy (JEOL-JSM6380LV). Abundance

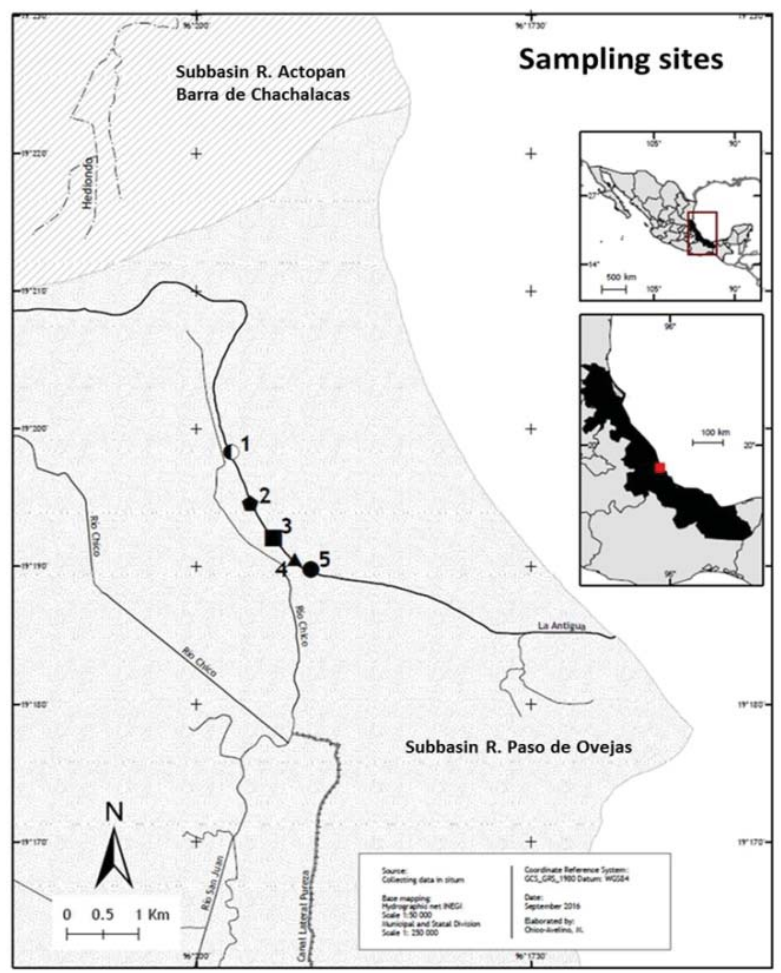

Fig. 1 : Geographical location of the basin Antigua River, Veracruz, Mexico and sampling stations 
was expressed as number of cells per milliliter (cell $\mathrm{ml}^{-1}$ ). Biomass was calculated as biovolume $\left(\mathrm{mm}^{3} \mathrm{~m}^{-3}\right)$ by approximation to the closest geometric forms (Sun and Liu, 2003) using average values of a minimum of 15 individual measurements for each identified species and multiplying by the species abundance (cell $\mathrm{ml}^{-1}$ ).

A diagram of Holston-Tukey was performed to identify the dominant, constant, temporary and rare species. With the taxa identifiedat system (dominant, constant and temporary) Detrended Correspondence Analysis (DCA) was applied using Project R Program 3.1.3 to relate species with environmental variables. The same analysis was utilized to identify temporal dominance of algal groups and spatial heterogeneity between stations. Shannon-Wiener Diversity Index was derived using Primer Program 6.1.6.

\section{Results and Discussion}

Mean water temperature was $26 \pm 3^{\circ} \mathrm{C}$; highest $\left(>28^{\circ} \mathrm{C}\right)$ corresponded to the dry period and decreased to $20^{\circ} \mathrm{C}$ in December. These values showed the tropical climate in the region. Mean depth value was $1.7 \pm 0.3 \mathrm{~m}$, increasing $\sim 0.3 \mathrm{~m}$ in wet months. Mean dissolved oxygen was $8.9 \pm 2.6 \mathrm{mgl}^{-1}$, with the highest value in the dry season (April, $19.1 \mathrm{mg} \mathrm{l}^{-1}$ ), and the lowest during the rainy season (mean $8 \mathrm{mg} \mathrm{l}^{-1}$ ) (Table 1). Turbulent water movement contributed to the relatively high values of dissolved oxygen but photosynthesis produced higher values.

Mean $\mathrm{pH}$ was $7.8 \pm 0.4$, with maximum value in October and April and $\sim 7.5$ during the rainy period. Mean turbidity value was 10.6 \pm 7.2 NTU, with maximum value in rainfall (September, 22 NTU) and minimum in dry season (January to May, $\leq 5$ NTU). Mean conductivity was $488 \pm 432 \mu \mathrm{S} \mathrm{cm}{ }^{-1}$, presenting a strong gradient in the driest months (December to May) disappearing with the rains (Table 1).

Mean SRP and nitrate were $2.6 \pm 2.6 \mu \mathrm{gl}^{-1} \mathrm{PO}_{4}^{-3}-\mathrm{P}$ and $0.6 \pm 0.5 \mathrm{mg} \mathrm{l}^{-1} \mathrm{NO}_{3}-\mathrm{N}$. Highest values for both were recorded during the rainy season $\left(>3 \mu \mathrm{gO}_{4}^{-3}-\mathrm{P}\right.$ and $\left.>0.6 \mathrm{mg} \mathrm{l}^{-1} \mathrm{NO}_{3}-\mathrm{N}\right)$ (Table 1).

Table 1 : Physico-chemical parameters (mean, standard deviation, range) determined in La Antigua River from March 2013 to February 2014

\begin{tabular}{llll}
\hline Variable & Unit & Mean \pm SD & Range \\
\hline Temperature & ${ }^{\circ} \mathrm{C}$ & $26 \pm 3$ & $(20.4-30.8)$ \\
Depth & $\mathrm{m}$ & $1.7 \pm 0.3$ & $(1.16-2.50)$ \\
Oxygen & $\mathrm{mgl}^{-1}$ & $8.9 \pm 2.6$ & $(5.6-19.1)$ \\
pH & & $7.8 \pm 0.4$ & $(6.8-9.2)$ \\
Turbidity & $\mathrm{NTU}$ & $10.6 \pm 7.2$ & $(2.3-28.2)$ \\
Conductivity & $\mu \mathrm{Scm}^{-1}$ & $488 \pm 432$ & $(130-1878)$ \\
SRP & $\mu \mathrm{gl}^{-1}$ & $2.7 \pm 2.6$ & $(0.15-11.8)$ \\
Nitrates & $\mathrm{mgl}^{-1}$ & $0.6 \pm 0.5$ & $(0.01-2.7)$ \\
\hline
\end{tabular}

Mean chlorophyll-a was $5 \mu \mathrm{g} \mathrm{I}^{-1}$; two pulses were recorded in October and February $\left(18.6 \mathrm{\mu g} \mathrm{l}^{-1}\right.$, and $11.8 \mathrm{\mu g} \mathrm{l}^{-1}$, respectively) (Fig. 2).

The mean phytoplankton biovolume was $5386 \mathrm{~mm}^{3} \mathrm{~m}^{-3}$, with peaks in March, April and October (11545; 32866 and 9115 $\mathrm{mm}^{3} \mathrm{~m}^{-3}$, respectively). About 200 taxa of microalgae were

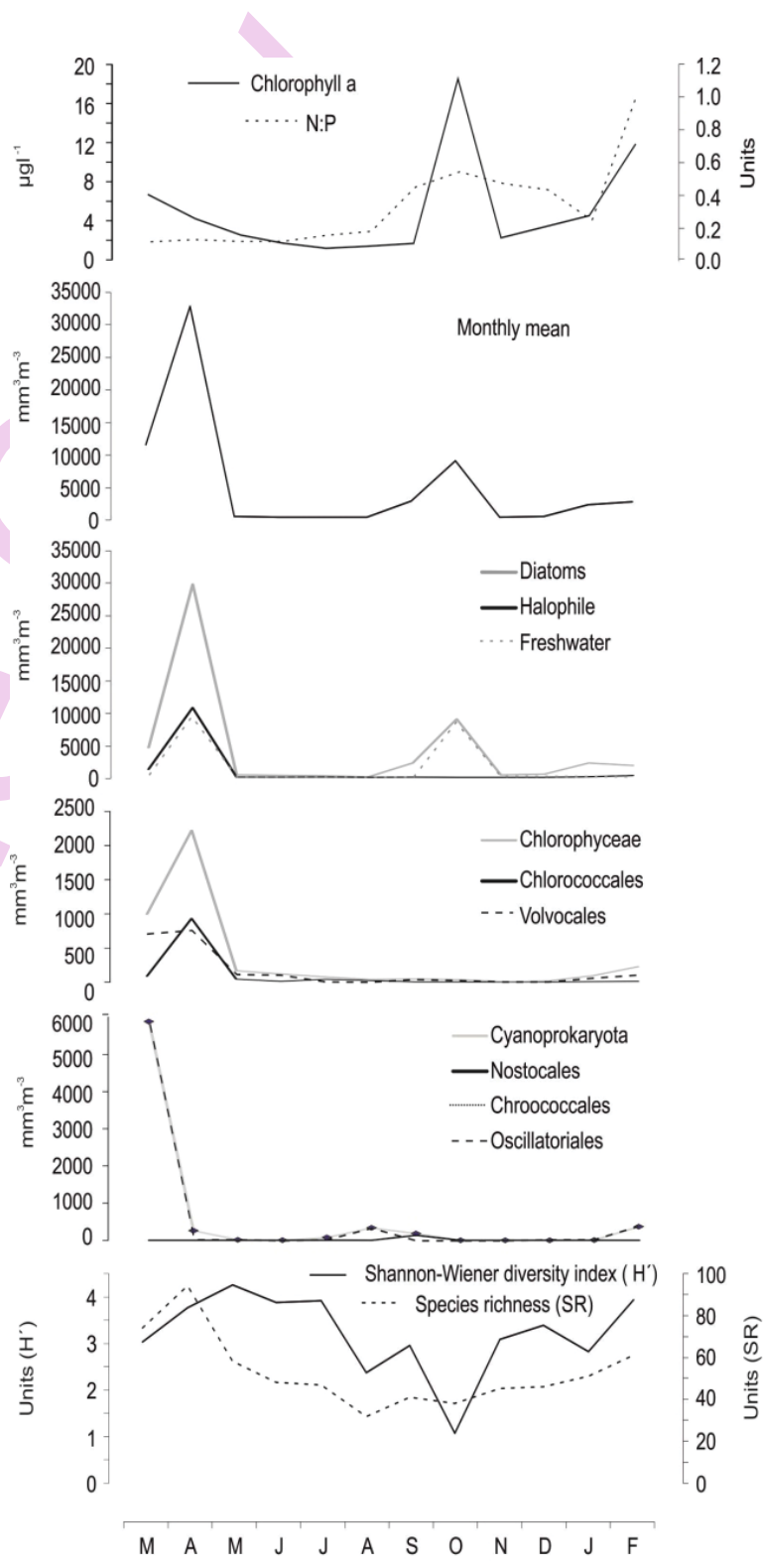

Fig. 2 : Variation of chlorophyll-a, N:P ratio; total phytoplankton biovolume; diatoms, Chlorophyceae and Cyanoprokaryota biovolume; diversity index and species richness, in La Antigua River, from March 2013 to February 2014

Journal of Environmental Biology, Special issue, November 2017 


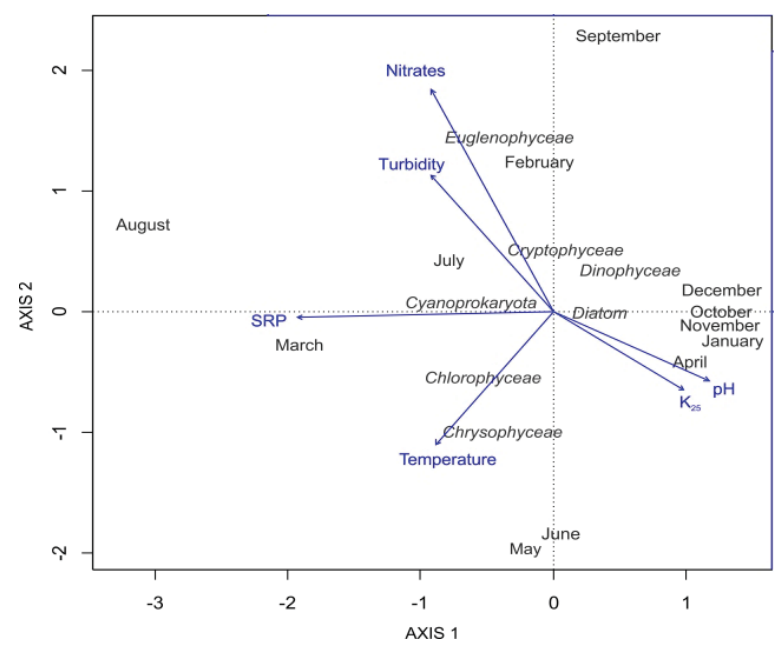

Fig. 4 : Temporal succession of algal groups throughout the study period

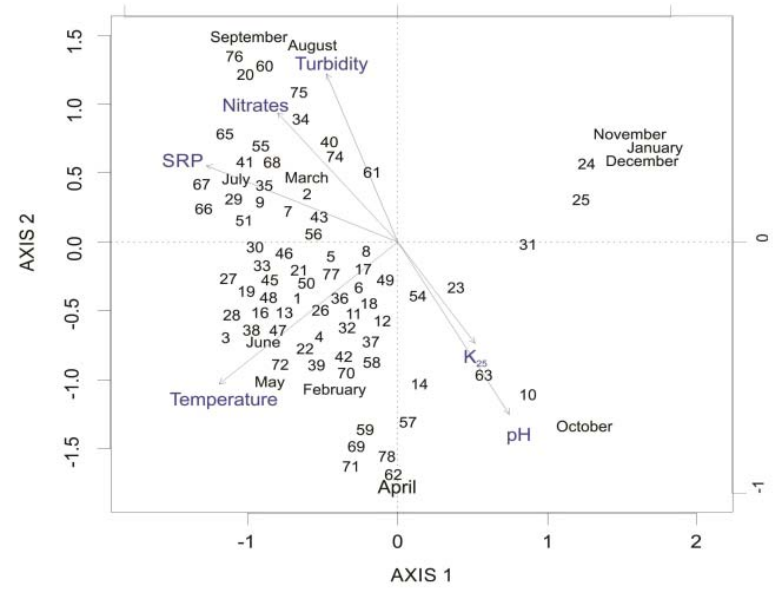

Fig. 5 : Distribution of dominant, temporary and constants species through the study period. Other details as in Fig. 3

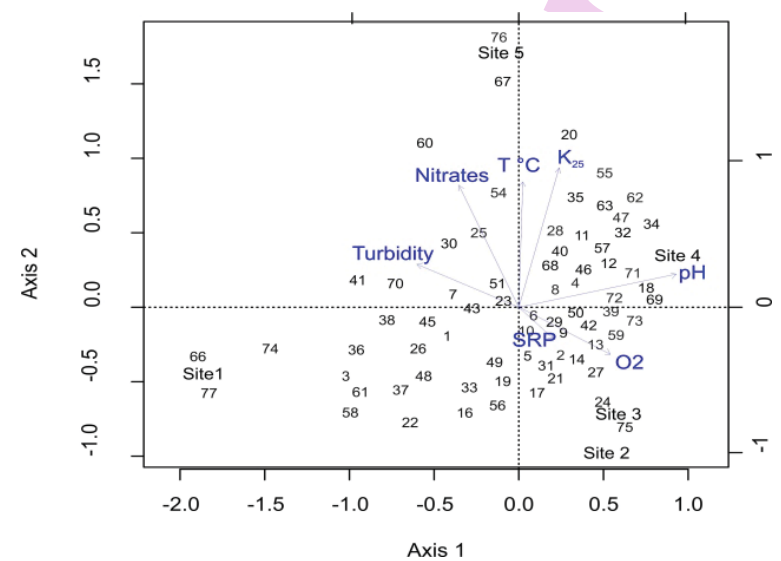

Fig. 6 : Distribution of dominant, temporary and constants species through stations sampled. Other details as in Fig. 3
Low volume of freshwater allowed the entrance of a wedge of salt into the river channel, establishing a gradient: Stations 1 to 4 were classified as freshwater $\left(<1000 \mu \mathrm{S} \mathrm{cm}^{-1}\right.$; Wetzel, 2001), while Station 5 exhibited brackish conditions $\left(1569 \mu \mathrm{S} \mathrm{cm}{ }^{-1}\right)$. Due to saline stress, teratological forms of $F$. goulardii, a freshwater species, were observed (Falasco et al., 2009), and hence low species richness would be expected (Lampert and Sommer, 2007).

However, the greatest richness of phytoplankton species found can be explained by the diversity of contributions: planktonic halophytes and benthic polyhalobes (Gardes et al., 2011; López et al., 2010), such as Thalassiosira weissflogii (Grunow) G. Fryxell \& Hasle; Amphora holsatica (Hustedt) sensuKrammer and Lange-Bertalot; Tryblionella compressa var. elongata (Grunow) L. Bert.; Tryblionella compressa var. compressa (J.W. Bailey) M. Poulin from sea. There was also a large biovolume of planktonic freshwater taxa: Fragilaria goulardii (Brébisson ex Grunow) L. Bert.; Synedraulna (Nitzsch) Ehrenberg; Cyclotella meneghiniana Kützing [diatoms]; Pandorina morum (O.F. Müller) Bory; Eudorina sp. [Volvocales]; Tetraselmis cordiformis (H.J. Carter) Stein [Chlamydomonadaceae]; Desmodesmus quadricauda (Turpin) Hegewald; Pediastrum boryanum (Turpin) Meneghini, [Chlorococcales]; Oscillatoria princeps Vaucher ex Gomont [cyanoprokaryota].

Volvocales, Chlamydomonadacea, Chlorococcales, Euglenophyceae, Cryptophyceae and Dinophyceae are mixotrophic and can incorporate organic material to survive without photosynthesis. Therefore, these are considered as good indicators of organic pollution (Reynolds 1998), confirming the contamination reported in this system. 0 . princeps related to high SRP indicating concentration of contaminants by evaporation (Fig. 4).

Rainy season : In this season, conductivity decreased due to dilution with fresh water; values of depth, amount of sediment (which is reflected in turbidity), and nutrients (mainly nitrates) were increased. Phytoplankton growth decreased due to the lack of light by an increase in turbidity and higher velocity of water flow. This was observed in the drastic reduction of chlorophyll-a, biovolume and algal richness. The species present were benthic, such as Navicula capitatoradiata H. Germain and Nitzschia palea (Kützing) W. Smith. In September, the month with heavy rains, Euglenophyceae and 0 . princeps indicated the presence of organic matter.

Cold - moderate rainy season: Favorable conditions for microalgae growth (mainly F. goulardii and S. ulna) were restored in October; low turbidity, increased nitrogen, and freshwater (mean K25 $380 \mu \mathrm{S} \mathrm{cm}^{-1}$ ) resulted in the highest chlorophyll-a values. In this respect, the $\mathrm{pH}$ and dissolved oxygen values were higher.

Journal of Environmental Biology, Special issue, November 2017 
However, low species richness was observed. Salinity gradient was restored in November, and apparently this affected the growth of algae, since the biovolume decreased and abundance of $C$. meneghiniana, $N$. capitatoradiata, N. palea, $T$. codiformis, species tolerant to changes in the salinity, were observed. The presence of diatoms and Dinophyceae associated with high conductivity could provide evidence of the input of marine phytoplankton, since they are the dominant groups in the sea (Muciño-Marquez et al., 2011).

Rainfall in November, December and January (CONAGUA, 2011), accentuated by El Niño meteorological phenomenon, contributed nitrates to the environment, promoting more balanced conditions with respect to $\mathrm{N}: \mathrm{P}$ ratio (Angulo and González, 2008), generating a small but sustained algal biovolume until February, when a pulse of biovolume and species richness was reached. The best quality of food represented by the increase in diatoms, and the highest diversity index confirmed the best conditions in this period.

The increase inphytoplankton after rainfall is a pattern described for other rivers, for example Sali River and Piedra Blanca River, in Argentina (Luque and Luján, 2003; Martínez de Marco and Tracanna, 2012), with a species richness similar to that recorded here (221 and 149 taxa, respectively).

Contribution of marine species to specific richness was also recorded at the mouth of Papaloapan River in Mexico (Moreno-Ruiz et al., 2008). The high species richness resembles other coastal systems such as the entrance to Sontecomapan lagoon in Mexico, which has high species richness (MuciñoMarquez etal., 2011).

Regarding zonation, station 1 was separated from stations 2 and 3 which constituted the area with the highest contamination by wastewater discharges of the population of $\mathrm{La}$ Antigua. Stations 4 and 5 were separated due to increases in salinity. These stations are the closest to the sea. Station 1 is likely to be cleaner and less salty. The predominance of diatoms in river systems is well documented (Luque and Luján 2003; Martínez de Marco and Tracanna, 2012) and focuses on the presence of structures such as raphe, which allow them to adhere to various types of substrates such as rocks, gravel, even vegetation. Range of the Shannon-Wiener index, which ranged from 1 to 3 , would indicate water from clean to slightly polluted (PérezMunguía et al., 2007).

\section{Acknowledgments}

This work was done with the support of DGAPA/PAPIIT IN213413 Project and FES-I/PAPCA 26 Project. We thank Rafael Quintanar and César Flores for support in Scanning Electron Microscopy at the Department of Biotechnology and Prototypes, FES-Iztacala and special thanks by map elaboration to Biol.
Monica Chico-Avelino and Raymundo Montoya-Ayala, GIS Laboratory and Remote Perception, UNAM-FES-IztacalaUBIPRO.

\section{References}

APHA: Standard methods for the examination of water and wastewater.18th Ed. APHA, AWWA, WPCF. Washington DC, USA (1995).

Angulo, F.F. and L.A. González: El fenómeno del Niño en México, un estudio de caso: la cuenca del Papaloapan, Veracruz [El Niño in Mexico, a case study: Thebasin of the Papaloapan, Veracruz]. In: Aires y lluvias. Antropología del clima en México [Airs and rain. Anthropology climate in Mexico]. (Eds.: A. Lammel, M. Gobubinoff and E. Katz) Centro de Estudios Mexicanos y Latinoamericanos, Mexico [Center for Mexican and Latin American Studies, Mexico.], pp. 567-590(2008).

Battarbee, R.W.: Diatom analysis. In: Handbook of Holocene Palaeoecology and Palaeohydrology (Ed.: E.B. Berglund). John Wiley and Sons, Chichester, pp. 423-448 (1986).

Carmona, J.J. and O. Necchi: A new species and expanded distributions of freshwater Audouinella (Acrochaetiaceae, Rhodophyta) from Central Mexico and south-eastern Brazil. Eur. J. Phycol., 36, $217-$ 226 (2001).

Cartajena, M.G. and J. Carmona: Morphological and ecological characterization of Charales (Chlorophyta) from calcareous tropical streams in Mexico. Cryptogam. Algol., 30, 1-16 (2009).

CONAGUA [National Water Commission]: Atlas del Agua en México [Water Atlas in Mexico] (2011).

CONABIO [National commission for the knowledge and use of Biodiversity]: Programa de regioneshidrológicas prioritarias [Program of priority hydrological regions] (2000).

Comas, A.: Las Chlorococcales dulceacuícolas de Cuba [The freshwater Chlorococcales of Cuba]. Bibliotheca Phycologica. Band 99. J. Cramer, Berlin-Stuttgart (1996).

Ekholm, P.: N:P ratios in estimating nutrient limitation in aquatic system. Finnish Environment Institute. http://www. cost 869. alterra. nl/FS/FS_NPratio. (2008).

Falasco, E., F. Bona, G. Badino, L. Hoffmann and L. Ector: Diatom teratological forms and environmental alterations: A review. Hydrobiologia, 623, 1-35(2009).

Gardes, A., M.H. Iversen, H.P. Giossart, U. Passow and M.S. Ulrich: Diatom-associated bacteria are required for aggregation of Thalassiosira weissflogii. ISME J., 5, 436-445 (2011).

Kirk, J.T.O.: Light and photosynthesis in aquatic ecosystem. Cambridge University Press, Oxford (2011).

Komárek, J.: Coccoid and colonial cyanobacteria. In: Freshwaters algae of North America. Ecology and classification (Eds.: J.D. Wehr and R. G. Sheat). Academic Press, New York, pp. 117-196 (2003).

Komárek, J. and K. Anagnostidis. Cyanoprokaryota 1 Teil: Chroococcales. Susswasserflora von Mitteleuropa. Gustav Fischer, Jena-Stuttgart (1999).

Komárek, J. and K. Anagnostidis: Cyanoprokaryota 2 Teil/ 2nd Part: Oscillatoriales. Susswasserflora von Mitteleuropa 19/2. Elsevier/Spektrum, Heidelberg (2005).

Krammer, K. and H. Lange-Bertalot: Süßwasser flora von Mitteleuropa. Band 2/1: Bacillariophyceae. 1. Teil: Naviculaceae. Gustav Fisher, Jena-Stuttgart(1986).

Krammer, K. and H. Lange-Bertalot: Süßwasser flora von Mitteleuropa. Band 2/2: Bacillariophyceae. 2 Teil: Bacillariaceae, 
Epithemiaceae, Surirellaceae. Gustav Fisher, Stuttgart \& New York (1988).

Krammer, K. and H. Lange-Bertalot: Süßwasser flora von Mitteleuropa. Baccillariophyceae. 3. Teil: Centrales, Fragilariaceae, Eunotiaceae. Gustav Fisher, Jena-Stuttgart (1991a).

Krammer, K. and Lange-Bertalot, H. Süß wasser flora von Mitteleuropa. Bacillariophyceae. 4. Teil: Achnanthaceae, Kristiche Ergänzungezu Navicula (Lineolatae) und Gomphonema). Gustav Fisher, Stuttgart and New York (1991b).

Lampert, W. and U. Sommer: Limnoecology. Oxford University Press, New York (2007).

López, F.F.O., B.D.A. Siqueiros and N.R. Nelson: Benthic diatoms associated with mangrove environments in the northwest region of Mexico. CONABIO, UABCS, CICIMAR, IPN [National commission for the knowledge and use of Biodiversity. Autonomous University of Baja California South. Interdisciplinary Center of Marine Sciences of the National Polytechnic Institute], Mexico (2010).

Luque, M.E. and M. de F.A. Luján: Distribución temporal del fitoplancton y epifiton en el río Piedra Blanca (Córdoba, Argentina). [Temporal distribution of phytoplankton and epiphyton in Piedra Blanca River (Cordoba, Argentina)]. Limnética, 22, 19-34 (2003).

Martínez de Marco, S.N. and B.C. Tracanna: Temporal variations of the phytoplankton of the tributary rivers and emitter of the reservoir $C$. Gelsi (Tucuman, Argentina). Bol. Soc. Argent. Bot., 47, 323-340 (2012).

Montejano, Z.G., J. Carmona-Jiménez and E. Cantoral-Uriza: Algal communities from calcareus springs and streams in La Huasteca, central Mexico: Asynthesis. In: Aquatic Ecosystems of Mexico: Status and Scope (Eds.: M. Munawar, S.G. Lawrence, I.F. Munawar and D.F. Malley). Backhuys Publishers, The Netherlands, pp.135-149 (2000).

Montejano, G., M. Gold-Morgan and H. León-Tejera: Surveying the diversity of cyanoprokaryantes in poorly known regions: the case of the central region of Mexico. Archiv. fur. Hydrobiol. Supp. Algol. Stud., 117, 329-338 (2005).
Moreno-Ruiz, J.L., M. Tapia-García, Ma. C. González-Macias and Ma. G. Figueroa-Torres: Phytoplankton from Tehuantepec river, Oaxaca, Mexico and some biogeographical relationships. Int. J. Trop. Biol., 56, 27-54 (2008).

Muciño-Márquez, R.E., M.G. Figueroa-Torres and A. Esquivel-Herrera: Circadian variation of the phytoplankton community and its relationship to species forming harmful algal blooms in the mouth of Sontecomapan coastal lagoon, Veracruz, Mexico. Oceánides, 26, 19-31 (2011).

Pérez-Munguía, R., R. Pineda-López and M. Medina-Nava: Biotic integrity of aquatic environments. In: Perspective on water systems conservation in Mexico (Eds.: O. Sánchez, M. Herzig, E. Peters, R. Márquez and L. Zambrano). United States Fishes \& Wildlife Services, INE, SEMARNAT, University of San Nicolás de Hidalgo of Michoacán, Mexico, pp. 71-112 (2007).

Ramírez, R.R., J.J. Carmona and D.C. Martorell: Microhabitat and morphometric variation in two species of Prasiola (Prasiolales, Chlorophyta) from streams in central Mexico. Aquat. Ecol.,41, 161-168 (2007).

Ramírez, V.M., M.Y. Beltrán, G.M. Bojorge, J.J. Carmona, U.E.A. Cantoral and C.F. Valadez: Flora algal del río la Magdalena Distrito Federal, México [Algal flora of Magdalena River Federal District, Mexico]. Bol. Soc. Bot. México, 68, 45-67 (2001).

Sun, J. and D. Liu: Geometric models for calculating cell biovolume and surface area for phytoplankton. J. Plankton Res., 25, 1331-1346 (2003).

Valadez, C.F., J.J. Carmona and U.E.A. Cantoral: Lotic environments algae in the state of Morelos, Mexico. Anales Inst. Biól. Univ. Nac. Autón. México. Ser. Bot., 67, 227-282 (1996).

Wetzel, R.G.: Limnology: Lake and River Ecosystems. $3^{\text {rd }}$ Edn., Academic Press (2001).

Williams-Linera, G.: Forest fog in central Veracruz: Ecology, history and destiny in times of fragmentation and climate change. National Institute of Ecology, National Commission for the Knowledge and Use of Biodiversity,Xalapa, Mexico (2007). 